\title{
Electric Meter Reading And Recording Remotelyand Automatically
}

\author{
Retno Aita Diantari ${ }^{1}$, Riki Ruli A. Siregar ${ }^{2}$ \\ \{retno.aita@sttpln.ac.id ${ }^{1}$, riki.ruli@sttpln.ac.id $\left.{ }^{2}\right\}$ \\ ${ }^{1,2}$ STT-PLN. PLN tower. J1. Outer West Lingkar, DuriKosambi, Cengkareng, Indonesia 11750 \\ Electrical Engineering Departement,Sekolah Tinggi Teknik - PLN
}

\begin{abstract}
KWh meters is a tool to measure the electric energy usage with "kilowatt hour" unit. The current KWh metersdoesn't yet have a remote monitoring feature, so the process for monitoring, reading the value of electrical energy, as well as making the termination and turning on the $\mathrm{kWh}$ meter is done directly to the customer's premises. Surely this will take a long time and the service becomes less satisfactory. The objective of this research is to make a model of $\mathrm{kWh}$ reading system (kilowatt-hours) PLN household power meter for recording of electrical energy used as well as providing information on power usage that is used in real time and accessible through communication network. $\mathrm{kWh}$ model reading system is designed as a tool for reading $\mathrm{kWh}$ postpaid electricity meter PLN households in the recording of electronic meters automatically made from a distance using the communication media. To know the incoming load through $\mathrm{kWh}$ Meters postpaid paired a current sensor that serves to detect electric current. Load data in the process using a microcontroller directly displayed to the LCD screen and automatically stored data into the database.
\end{abstract}

Keywords : KWh meters, household customers, online.

\section{Introduction}

PLNis a company that serves all aspects of electricity and other related fields. The process of reading and recording the PLN electricity meter is a very important activity in the PLN business. During this time reading and recording on postpaid electricity meter is still using manual wich take picture or image from the position of the numbers listed on $\mathrm{kWh}$ meter by using phone having camera. This way of course in addition to being a complaint from the customer also the officer who record the meter. This customer complaint is caused the amount of usage does not match the amount paid, the customer sometimes always pay more than the amount of usage listed in kwh is caused by the image or image produced from the catering officer has a lot of noise that would reduce the quality of pictures or images. As for the difficulty of the officer that the officer is having trouble entering the house which has a fence and the fence is locked because the officer takes a $\mathrm{kWh}$ image if this happens the officer will not be able to take pictures or images of $\mathrm{kWh}$ houses that have fences (Prihartomo, Nyoto, \&Sukamto, 2015).

The model in $\mathrm{kWh}$ meter recording has been applied to get a full automatic billing system. It aims to measure and monitor the power consumed by the power of bills that are consumed automatically (Paul, 2016). Using this system, the power company can access all data about the power consumed in each home and at each station when necessary.

In this research will be discussed a new method is expected to be one solution to overcome the problems in recording electric meter is by using an application that can record 
the amount of electrical energy usage automatically made from a distance using the communication media.

\section{Kwh Meter}

KWh meter is a tool used by PLN to calculate large consumer power consumption. This tool is very common in the community. The main part of a $\mathrm{kWh}$ meter is a voltage coil, current coil, aluminium disc, fixed magnet to neutralize the aluminum disk from induction of magnetic field and mechanical gear which records the amount of aluminium disk rotation. There are two types of kwh, namely kWh Meter analog and kWh Meter digital (PLN, 2011).

Research has been done to determine the level of satisfaction users of postpaid $\mathrm{kWh}$ meters and prepaid $\mathrm{kWh}$ meters that average postpaidrespondents agreed to switch to $\mathrm{kWh}$ meter prepaid, but they still assume that $\mathrm{kWh}$ Postpaid meters are much more practical than prepaid kWh meters (Zulkarnain\&Fitrizawati, 2016).

In subsequent research using android platform device that has NFC communication technology (Near Field Communication)(Prihartomo, Nyoto and Sukamto, no date). NFC (Near Field Communication) is a technology-based wireless connectivity device based on RFID (Radio Frequency Identification) technology that uses magnetic field induction to enable communication between electronic devices in close proximity of designing an application of Digital KWh Recording Using NFC (Near Field Communication) as a communication device On Android Platform.

Research in establishing payment system design and charging pulse electricity prepay online. The ongoing prepaid electricity system still reaps a lot problems, for example, the system still requires electricity customers to buy credit electricity offline by visiting outlet sales outlets, ATMs, or through third party intermediaries. online in accordance with customer needs and can facilitate customers in purchasing token / pulse electricity and charging pulse power online and real-time. So the customer can do the charging pulse anytime and anywhere by using internet connection. Customers do not have to wait in line in front of ATMs, POS sales of electrical token, or not having to do the charging pulse electricity manually (Budianto\&Saragih, 2011).

\section{Research Method}

KWh Online Counting System Microcontroller at KWh serves to calculate the ongoing cycle in which the sensor is installed to calculate it. The microcontroller will then connect with the server through the GPRS network to make the data transmission. In this system there are admins and customers who can perform the process of checking the number of usage where the number of rounds will always update every day through a computer connected to the internet network (assuming the server gets fixed IP to be accessed via the internet). As seen in network topology, a network made for microcontroller communications using a GPRS module which sends data to a database server whose data is directly processed in the admin.

The loads used are entered through the analogkWh Meter. Then the incoming load has a current that can be detected using the current sensor. The load data is processed by arduino and displayed on the LCD. After that load data into the database that has been created and can be directly connected to the localhost network through the router so that data can be accessed through the web server. 


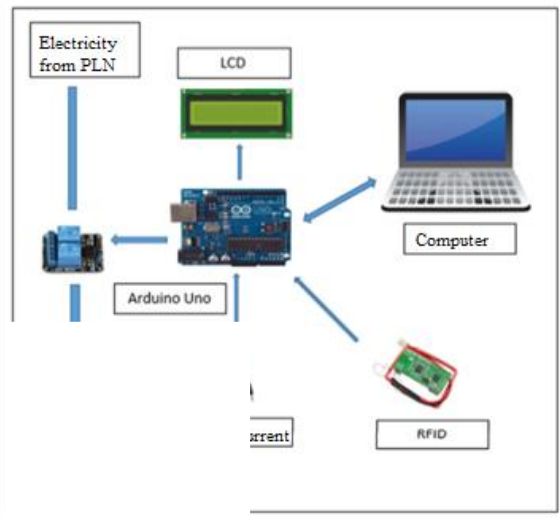

Fig.1. System KWH meters online

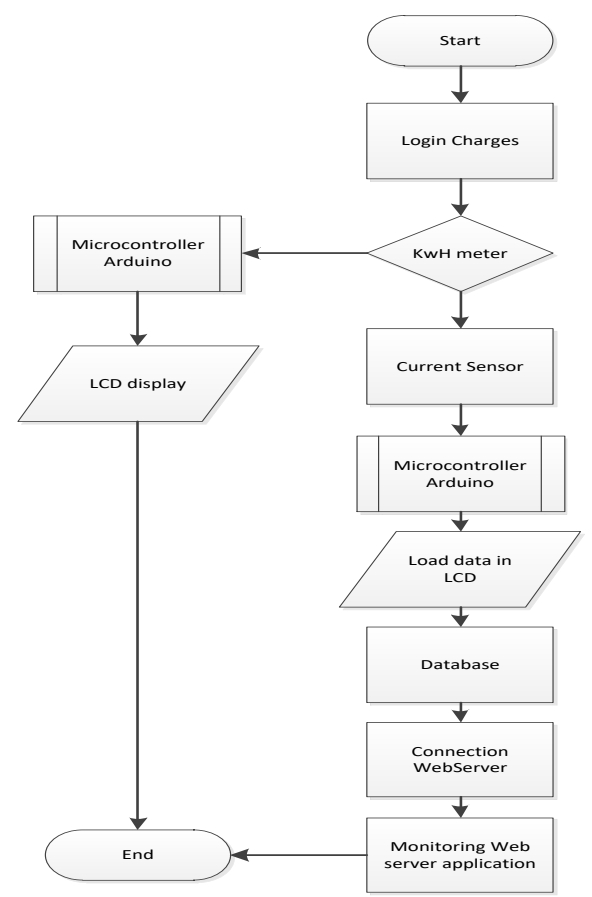

Fig.2. $\mathrm{kWh}$ Meter Data Reading

In the process of reading the $\mathrm{kWh}$ Meter data where if the load is detected by the current sensor it will enter into the arduino microcontroller process. In the arduino process the load is calculated to give the current and power values.

Design with Application aims to detect how much energy is used and will be stored in the database using MySql to help view history usage. With the use of integrated model web server will get history usage which aims in determining category of electric energy usage that will help PLN users /customers to know the household electricity usage. 


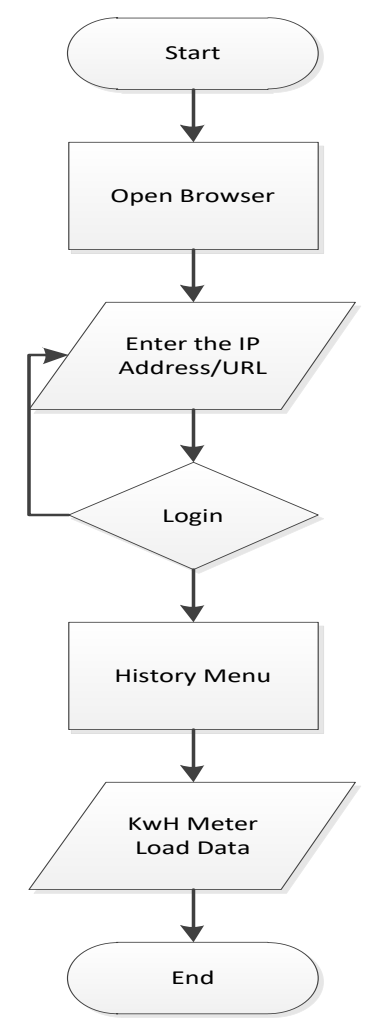

Fig.3. Application Flow Chart

KWh Meter will receive load from the use of household electrical that has been paired to the reading of data which includes current sensor as detector of current, arduino as microcontroller, ethernet shield to connect arduino with internet, and router as communication media. After the prototype of the tool to detect a current then the data will be sent nircable and then the data will be stored into the server. Data that has been entered into the server can be accessed by the meter meter through web already provided.

\section{Results And Discussion}

Based on the results of tests on $\mathrm{kWh}$ Meter data reader tool that has been done, then the following is the experimental image of the tool on the $\mathrm{kWh}$ Meter analogous to the load testing with some equipment tools that use electrical power. 


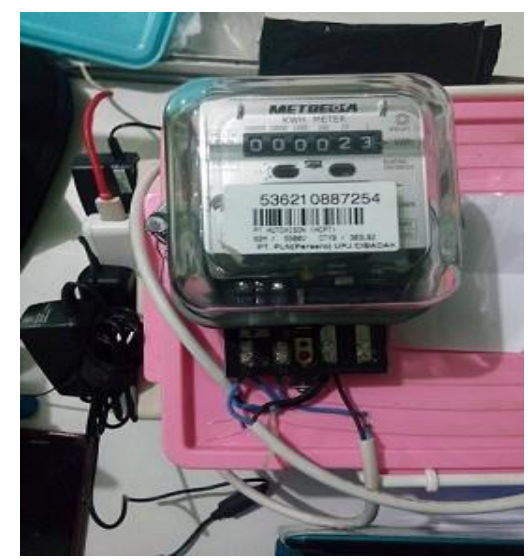

Fig.4 KWh Meter Analog

The load current that goes into the $\mathrm{kWh}$ The analog meter is detected by the current sensor which is then processed with the arduino and directly displayed on the LCD screen.

Testing model of kWh Meter reading tool. The load data that has current to the $\mathrm{kWh}$ Meter is detected by the current sensor which is then processed by the arduino and displayed on the LCD screen. After that the data directly into the server then the data can be accessed through the communication network.

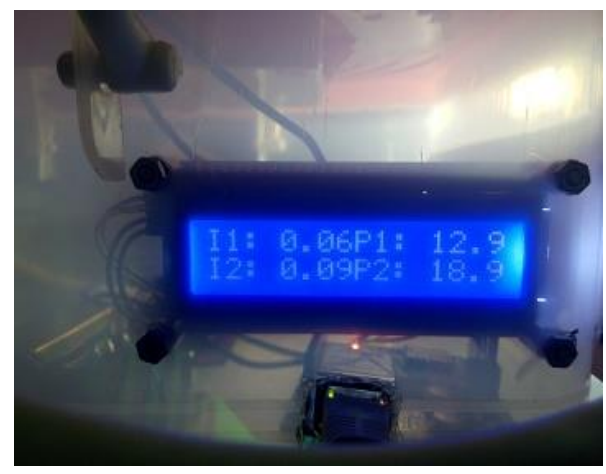

Fig.5. LCD Screen kWh meter model

Based on the results of trials on web server applications that have been done, then the following is a trial image web application server reading data $\mathrm{kWh}$ Meter using a web browser contained in android. In general, this application plays a role to assist officers in the process of monitoring and optimizing data recorded manually. So officers no longer need to record the meter to each customer's home. This can help speed and accuracy of officers in meter recording. 


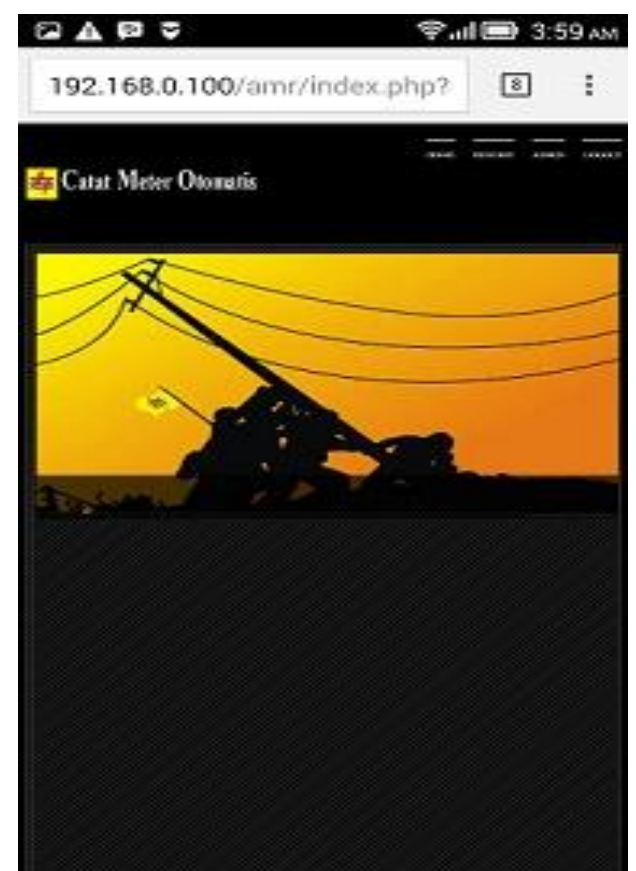

Fig.6. Main Menu

In the History menu there are 8 tables of input that can be used to enter data that need to be entered into the database. And there are 2 menu options for printing with pdfand microsoft excel. Also in the menu history there is a menu ofdatepicker options to sort the load data in accordance with the month and year that users choose. The menu aims to facilitate users in the search data each month. 


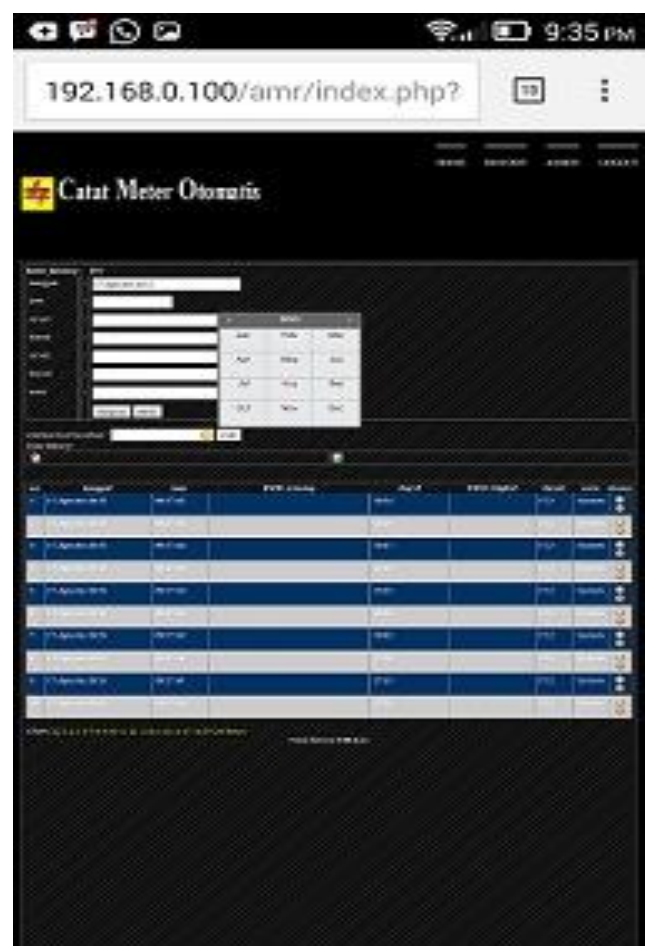

Fig.7. History Menu

\section{Conclusion}

In this paper, it can be concluded that the model electric meter postpaid reading and recording remotely and automatically can help PLN in the process of recording kwh meter customers so no need to send officers to come to every home. In this model use the help of communication transmission media and installation of embedded system in $\mathrm{kWh}$ meter to be readable. Load data is processed by using a microcontroller directly displayed to the LCD screen and automatically saves data into the database and can be accessed online by users and officers so that the recording of $\mathrm{kWh}$ meter is more accurate and realtime.

\section{References}

[1] Budianto, A., \& Saragih, H. (2011). Penerapan Sistem Listrik Pln Prabayar Dengan Penggunaan Dan Pengoperasian Kwh Meter Prabayar Secara It Dalam E-Payment Sistem Sistem Pulsa Listrik. Jurnal Sistem Informasi Vol. 7 No. 2,77 - 88.

[2] Bureau, \& Efficiensy, O. E. 2004. Energy Monitoring and Targeting. Syllabus.

[3] Diya Elizabeth Paul, Prof . Alpha Vijayan. 2016. Smart Energy Meter Using Android Application And Gsm Network. International Journal Of Engineering And Computer Science ISSN:2319-7242 Volume - 5 Issue -03 March, 2016 Page No. 16058-16063. India.

[4] Paul, D. E. (2016). Smart Energy Meter Using Android Application And Gsm Network. International Journal Of Engineering And Computer Science, 5(16058), 16058-16063. https://doi.org/10.18535/ijecs/v5i3.36. 
[5] PLN. (2011). Listrik Prabayar. Retrieved Mei 1, 2016, from PLN Site: http://www.pln.co.id.

[6] Polly, B., Kruis, N., \& Roberts, D. (2011). Assessing and Improving the Accuracy of Energy Analysis for Residential Buildings. Cole Boulevard: Office of Energy Efficiency and Renewable Energy, USA.

[7] Prihartomo, D. D., Nyoto, R. D., \& Sukamto, A. S. (2015). Rancang Bangun Aplikasi Pencatatan Pemakaian KWH ( Kilo Watt Hour ) Listrik Digital Menggunakan NFC ( Near Field Communication ) Sebagai Komunikasi Perangkat Pada Platform Android.

[8] Zulkarnain, S., \& Fitrizawati. (2016). Analisis Perbandingan Tingkat Kepuasan Pengguna Kwh Meter Pascabayar Dengan kWH Meter Prabayar. Instuisi Teknologi dan Seni, 8 No 1(ISSN-2497), 57-64.

[9] Prihartomo, D. D., Nyoto, R. D. and Sukamto, A. S. (no date) 'Rancang Bangun Aplikasi Pencatatan Pemakaian KWH ( Kilo Watt Hour ) Listrik Digital Menggunakan NFC ( Near Field Communication ) Sebagai Komunikasi Perangkat Pada Platform Android', pp. 1-5. 